\title{
Prospective observation of energy intake from birth to 1 year
}

\author{
E. M. Oliver ${ }^{1}$, K. E. C. Grimshaw ${ }^{1,2}$, K. Scally ${ }^{1}$, K. Foote ${ }^{3}$, G. Roberts ${ }^{1}$ and B. M. Margetts ${ }^{4}$ \\ ${ }^{1}$ Division of Infection, Inflammation and Immunity, Faculty of Medicine, University of Southampton, SO16 6YD, UK, \\ ${ }^{2}$ Department of Clinical Sciences, University of Chester, CH14BJ, UK, ${ }^{3}$ Department of Paediatrics and Child Health, \\ Royal Hampshire County Hospital, SO22 5DG, UK and ${ }^{4}$ Public Health Nutrition, Primary Care and Population Sciences, \\ Faculty of Medicine, University of Southampton, SO16 6YD, UK
}

No study has recorded and analysed what an infant consumes prospectively from birth until they reach 1 year of age with the use of food diaries since such a methodology is costly and can cause low respondent rates ${ }^{(1,2)}$. Such prospective data was collected for infants enrolled into the UK birth cohort of EuroPrevall (a multicentre research project funded by the EU looking into allergy) ${ }^{(3)}$ and was analysed to assess whether intake of macro- and micronutrients increased month on month and whether any difference in intake between the time points analysed was significant.

Enrolled infants had food diary records kept for their first year of life. Food diaries were completed and returned to the study office every 4 weeks. The fourth week of each diary contained quantitative data to allow detailed dietary analysis of intake and it was this data that was used in this work. Diaries were analysed using the dietary analysis program 'Comp-Eat' (Nutrition Systems) which had been modified to include nutritional data for all formula milks and baby food products recorded in the food diaries. Using available literature ${ }^{(1,4)}$, breast milk volumes were assigned based on the child's age in months and the total amount of other milks reported (infant formula, cow's milk).

A complete set of diaries (thirteen) were analysed for twenty-five infants (325 diaries in total). Mean percentage weight increase for these infants at 12 months of age was $312 \%$. Our data shows that energy intake does increase significantly over the infants first year $(P<0.000)$, there is a month on month increase in intake and this increase is significant between the ages of $0-4$ weeks, $4-8$ weeks, 20-24 weeks, 24-28 weeks and 36-40 weeks. Similar findings were seen for protein, fat, carbohydrate, $\mathrm{Ca}, \mathrm{Fe}, \mathrm{Se}, \mathrm{Zn}$ and vitamins A, C and $\mathrm{E}$.

\begin{tabular}{|c|c|c|c|c|c|c|}
\hline $\begin{array}{l}\text { Age } \\
\text { (weeks) }\end{array}$ & $\begin{array}{l}\text { Number of infants } \\
\text { receiving breast } \\
\text { milk at time point }(\%)\end{array}$ & $\begin{array}{c}\text { Number of infants } \\
\text { exclusively breast } \\
\text { fed at time point }(\%)\end{array}$ & $\begin{array}{l}\text { Mean energy } \\
\text { intake }(\mathrm{kJ} / \mathrm{d})\end{array}$ & $\begin{array}{l}\text { Change in daily } \\
\text { energy intake per } \\
\text { period }(\mathrm{kJ})\end{array}$ & $\begin{array}{l}\text { Standard } \\
\text { deviation }\end{array}$ & EAR $(\mathrm{kJ} / \mathrm{d})$ \\
\hline 4 & $22(88)$ & $14(56)$ & $2100.36^{*}$ & 133.88 & 47.48 & $2154.76-2280.28$ \\
\hline 8 & $18(72)$ & $10(40)$ & $2234.25^{*}$ & 200.83 & 67.66 & $2154.76-2280.28$ \\
\hline 12 & $17(68)$ & $7(28)$ & 2435.08 & 276.14 & 75.39 & $2154.76-2280.28$ \\
\hline 16 & $12(48)$ & $3(12)$ & 2585.71 & 104.6 & 96.97 & 2698.68-2886.96 \\
\hline 20 & 7 (28) & $2(8)$ & 2690.31 & 171.54 & 75.57 & $2698.68-2886.96$ \\
\hline 24 & $5(20)$ & $1(4)$ & $2861.85^{*}$ & 317.98 & 98.80 & $2698.68-2886.96$ \\
\hline 28 & $4(16)$ & $1(4)$ & $3179.84 *$ & 397.48 & 115.42 & $3200.76-3451.8$ \\
\hline 32 & $4(16)$ & 0 & 3577.32 & 225.93 & 106.75 & $3200.76-3451.8$ \\
\hline 36 & $3(12)$ & 0 & 3803.25 & 25.10 & 179.84 & $3200.76-3451.8$ \\
\hline 40 & $3(12)$ & 0 & $3828.36^{*}$ & 251.04 & 118.67 & $3619.16-3849.28$ \\
\hline 44 & $3(12)$ & 0 & 4079.4 & 33.47 & 172.93 & $3619.16-3849.28$ \\
\hline 48 & $3(12)$ & 0 & 4112.87 & 33.47 & 126.86 & $3619.16-3849.28$ \\
\hline 52 & $2(8)$ & 0 & 4200.73 & 87.86 & 141.17 & $3619.16-3849.28$ \\
\hline
\end{tabular}

Mean values were significantly different between this time point and the previous time point (RM ANOVA): $* P<0.05$.

These results suggest that Estimated Average Requirement's and Reference Nutrient Intakes for infants aged between 0 and 1 year would be better expressed as monthly values since intakes increase month on month in the first year of life and grouping these values limits their accuracy.

This work was funded by Food Standards Agency, UK.

1. Butte NF, Fox MK, Briefel RR et al. (2010) J Am Diet Assoc 110, S27-S37.

2. Butte NF (1996) Eur J Clin Nutr 50, S24-S36.

3. Kiel T, McBride D, Grimshaw KEC et al. (2010) Allergy 65, 482-490.

4. Dewey KG \& Lonnerdal B (1983) J Pediatr Gastroenterol Nutr 2, 497-506. 